\title{
Activity-based costing (ABC) Model for Public Higher Education Institutions (PHEI) : A guide for a Model development
}

\author{
Dr. Jamalludin Helmi HASHIM. Ph.D \\ Faculty of Business Administration and Accounting \\ Universiti Sultan Zainal Abidin (UniSZA) \\ MALAYSIA
}

\begin{abstract}
The purpose of this study is to develop the Activity-based costing (ABC) model for Bachelor of Accountancy (BACC) program in University of Excellence (UoE) Malaysia. A case study approach using the professional software, ABMSAS, and the actual expenses figure for BACC for the year 20XX were used to develop the ABC model in this study. The finding showed that the cost computed using the $A B C$ Model is lower as compared to the cost from the traditional (current) method, i.e. RM 8,678.54 and RM 10,509.99, respectively. The differences amounted RM 1,830.55 in cost calculated by these two systems is not surprising. It is expected as many other researchers have discovered the same pattern on the lower cost of $A B C$ as compared to the traditional method due to several reasons. Among others are, (i) the inability of the traditional costing system in spreading their costs over larger numbers of students, ii) the support services do not benefit the programmes uniformly and, iii) there were internal cross-subsidies among departments and seriously distorted if support costs were allocated based on head counts. As such, this study confirmed the ability of $A B C$ to act in higher education institutions with the same functions as its functions in the profit and manufacturing setting
\end{abstract}

Keywords: Activity-based Costing (ABC) Model, Traditional costing system, Case Study, Public Higher Education Institutions (PHEI), Cost comparison.

\section{Council for Innovative Research}

Peer Review Research Publishing System

Journal: International Journal of Management \& Information Technology

Vol. 7, No. 3

editor@cirworld.com

www.cirworld.com, member.cirworld.com 


\section{INTRODUCTION}

The substantial amount of expenditure on education faces by Higher Education Institutions (HEI) requires universities' administrations to have a more sophisticated costing technique, like Activity-Based Costing (ABC). Several benefits of ABC in HEI were provided by Tatikonda and Tatikonda (2001), which, among others are: (i) better cost information; (ii) better distribution of scarce resources; (iii) better course and programme mix; (iv) better cost control; and (v) better public relations tool.

Even though the use of $A B C$ is rapidly gaining favour in service organisations (Khrisnan, 2006; Newman, 2003), very limited research has been done on the technical issue of the model development of $A B C$, particularly in the public $\mathrm{HEI}$. While there were evidences on a very little effort has been done to implement $A B C$ in universities, this is partly due to the technical complexity of the ABC Model itself (Cohen et al., 2005; Jamaliah Abdul Majid and Maliah Sulaiman, 2008).

The objectives of this article are threefolds: (i) to highlight the weaknesess of the traditional costing system, ii) to explain a detail steps to develop the ABC Model for UoE Branch A, Malaysia and iii) to compare the cost generated between these two costing systems.

\section{ACTIVITY BASED COSTING (ABC) VERSUS TRADITIONAL COSTING SYSTEM (TCS)}

\subsection{Definition and Concept}

Activity-based Costing $(A B C)$ is a two-stage procedure used to assign overhead costs to products or services (Hilton, 2001). In the first stage, significant activities are identified, and overhead costs are assigned to activity cost pools in accordance with the way resources are consumed by the activities. In the second stage, the overhead costs are allocated from each activity cost pool to each product line in proportion to the amount of the cost driver consumed by the product line. ABC differs from traditional cost accounting, such that overhead costs are traced to products or services using cost pools and activity cost drivers rather than volume based overhead absorption rates. Basically, $A B C$ assumes that products consume activities and activities consume overhead resources (Clarke and Mullin, 2001). Therefore, $A B C$ is able to measure the cost and performance of activities, resources and cost objects.

As such, $A B C$ recognises the causal relationship of cost drivers to activities (Holst and Savage, 1999) and can be viewed as "cost assignment" (refer to Figure 1: vertical axis) used for profitability analysis (Cokins, 1996). Its consisted of Resources, Activities and Cost Object Module. Additionally, ABC can be viewed from a process view (refer to Figure 1: horizontal axis) perspective, which consisted of Activities, cost drivers and activities management.
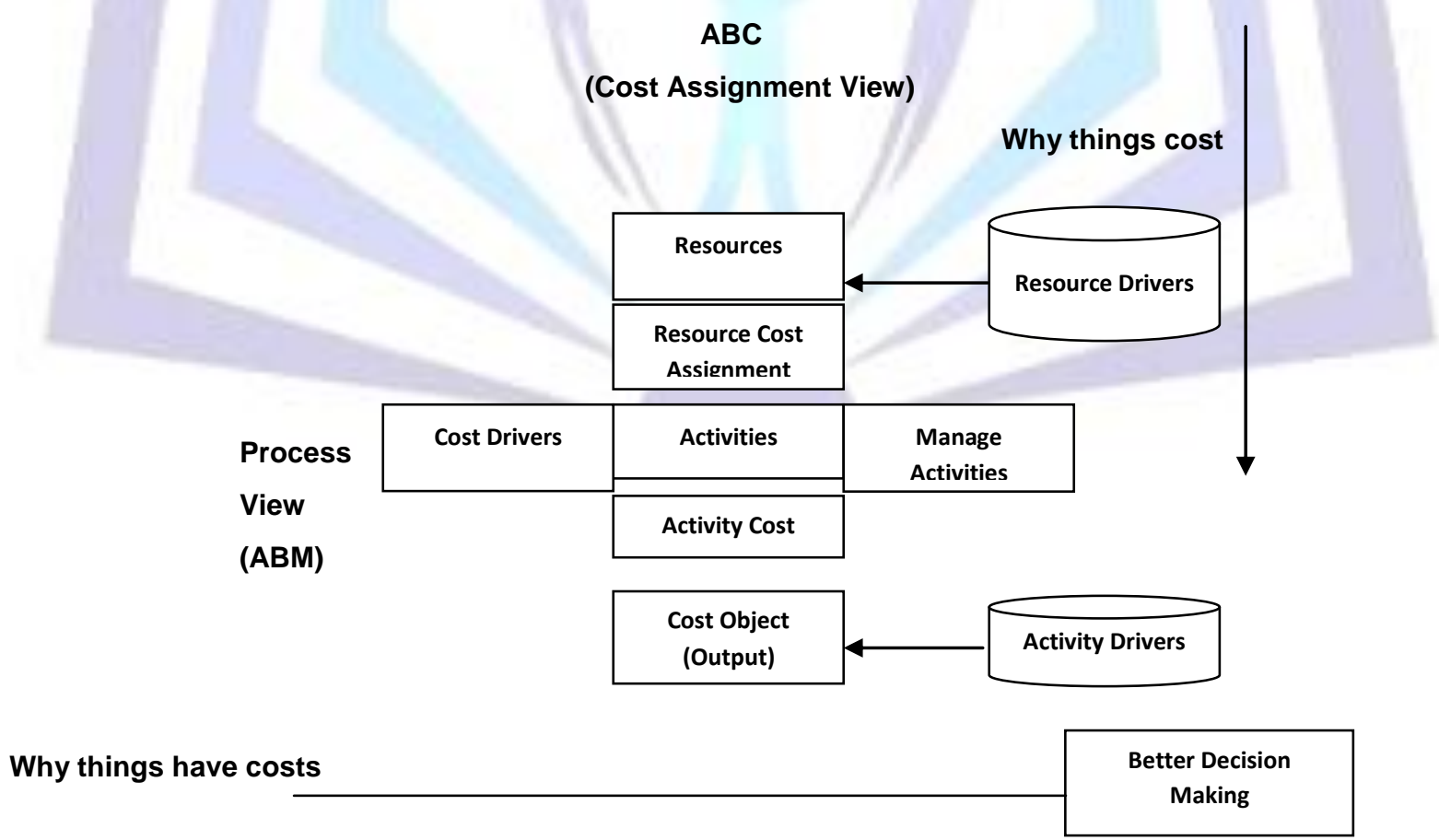

Source: Cokins, 1996, p.15. Figure 1 : Activity Based Cost Management Framework. 


\subsection{Limitations of Traditional Costing System (TCS)}

Based on an interview with Mr Sanip Wahid, UoE's Bursary, the list of the limitation to the existing costing system are, i) Chart of Accounts, ii) Emolument information, iii) Expenses for part time lecturers, iv) direct and indirect cost and v) depreciations ${ }^{1}$ :

The charts of accounts (COA) are not based on cost centres. In Main Campus, the COA is based on faculty and not based on the level of courses offered. It is suggested to use the COA as a cost centre at the programme level and the unit level is to be used as a service cost centres. Other than that, the emolument expenses are charged based on the lecturers in their respective faculties and not on FTE (Full-Time Equivalent) where they served. For example, a lecturer who taught Diploma in Accountancy with 12 credit hours (or 0.75 FTE) and also taught Diploma in Business Studies with another 4 credit hours (or 0.25 FTE), the emolument will be divided into two parts - 75 percent for Diploma in Accountancy and another 25 percent for Diploma in Business Studies. The same problem goes to the expenses incurred for part-time lecturers, which they are also being charged based on their locations and not on the basis of cost centres.

With regard to the direct and indirect cost, until today there is no accurate formula to record and analyse the portion of the direct and indirect costs in the UoE system as a whole. For example, electricity expenses in the main campus need to be allocated using some basis, such as floor area, time allocation etc. For Research \& Development (R\&D), total cost at branch campuses should be based on the student ratio using weightage (EFTS) and weightage course category (based on the average costs at the main campus). The estimation is based on EFTS to the total expenses at either Main Campus or branch campuses to differentiate between direct and indirect costs. Other than that, the information about depreciation is also not properly recorded. The current exercise is to charge depreciation to the Bursary office. It is suggested that the depreciation of assets need to be recalculated if any additional assets are purchased within five years (for example, 2010-2014).

The above discussions have led to the growing concern for the usefulness of costing information in public universities. The usage of the cost information produced by the existing costing system is very limited in enhancing accountability and transparency. Other than that, the call for public universities to generate 30 percent of the operating expenses have added pressure for a more accurate costing system. Universities administration needs detailed cost information to ensure optimal utilisation of resources.

\subsection{Benefit of $\mathrm{ABC}$ in $\mathrm{HEI}$}

Particularly in HEI sector, $\mathrm{ABC}$ was claimed to provide more accurate cost management by its ability to calculate the 'true' cost of a product (Amizawati Mohd Amir et al., 2012; Tatikonda and Tatikonda, 2001), more reliable method to report, define and capture time spent by faculty within specified activities. These abilities contribute to the overall performance of the university (Cox et al., 2007). Other than that, ABC system is also seen to be flexible with specific characteristics and enable the management to focus on a specific faculty (Noor Azizi Ismail, 2006) and support services (Khrisnan, 2006) in HEl.

\section{TRADITIONAL COST CALCULATION IN UOE}

There are four steps involved to calculate the cost per programme for UoE Branch A, Malaysia as listed and briefly explained below:

Step 1: Calculate the overall cost per student

To calculate the overall cost per programme, the total expenses of the specific period or year (in this case 20XX) were divided with the number of students (overall) which was estimated to be $\underline{7,044}$. Thus, the average cost per student is amounted to RM 2,556.96.

\section{Step 2: Calculate the overall cost per Bachelor's student.}

As this amount represents the cost per student, some weighted need to be considered. With regard to this, UoE Main Campus practices some rules. As UoE Main Campus segregated the cost based on the level of academic, they put the different weighted for different level of education, as listed in Table 1. The overall cost per Bachelor's student is amounted RM 3,835.44. 
Table 1 : Weightage for Equivalent Full Time Students (EFTS)

\begin{tabular}{||l||c||}
\hline \hline EQUIVALENT FULL TIME STUDENT & Weightage \\
\hline \hline Level of Educations & \\
\hline Pre, Diploma- Distance Learning & 0.50 \\
\hline Matriculation & 1.00 \\
\hline Certificate: Off Campus Diploma & 0.75 \\
\hline Diploma, Bachelor Degree- Off Campus & 1.00 \\
\hline Bachelor Degree & 1.50 \\
\hline Master Degree Professional Post-Graduate & 2.00 \\
\hline
\end{tabular}

Step 3: Calculate the overall cost per student for Bachelor's of Accountancy.

As this amount represents the cost per student for BACC and the rules stated that different faculty required different portions of overhead, the weighted of stated need to be added to this amount. As such, the weighted listed in Table 2 is calculated to arrive at the total amount of cost per student for BACC, which amounted to RM 5,254.55.

Table 2 : Weightage for Faculty

\begin{tabular}{||l|c||}
\hline \multicolumn{1}{|c||}{ WEIGHTAGE - COST AVERAGE } & Weightage \\
\hline \multicolumn{1}{|c||}{ Faculties } & \\
\hline $\begin{array}{l}\text { Accountancy, Law and Administration, Business } \\
\text { Administration, Education, Hotel and Tourist } \\
\text { Management, Information Studies, Language Centres }\end{array}$ & 0.37 \\
\hline $\begin{array}{l}\text { Applied Science, Building, Planning and Surveyor, } \\
\text { Civil Engineering, Electrical Engineering, Mechanical } \\
\text { Engineering, Art and Design, Information Technology } \\
\text { and Quantitative Science, Public Admin, Office } \\
\text { Technology and Management, Sports and } \\
\text { Recreational Science, Health Technology }\end{array}$ & 0.63 \\
\hline
\end{tabular}

Step 4: Calculate the overall cost per student for Bachelor's of Accountancy student for UoE Branch A.

This amount represents the cost per student for BACC. It is normal procedure for UoE to differentiate the overhead allocated from Main Campus based on campus location. Table 3 lists the different weighted charged to the different location. After the calculation, it is shown that the cost per student for BACC in UoE Branch A amounted to RM 10,509.10.

Table 3: Weightage for Campus Location

\begin{tabular}{|l|c|}
\hline \multicolumn{1}{|c|}{ Campuses } & Weightage \\
\hline Southern Zone campuses & 1.5 \\
\hline East Coast Zone Campuses & 2 \\
\hline Central Zone campuses & 1 \\
\hline East Malaysia Zone Campuses & 3 \\
\hline
\end{tabular}

Source: Interviewed with the Bursary of UoE

Figure 2 shows the graphical presentation of the traditional cost calculation BACC for UoE Branch A Malaysia. 


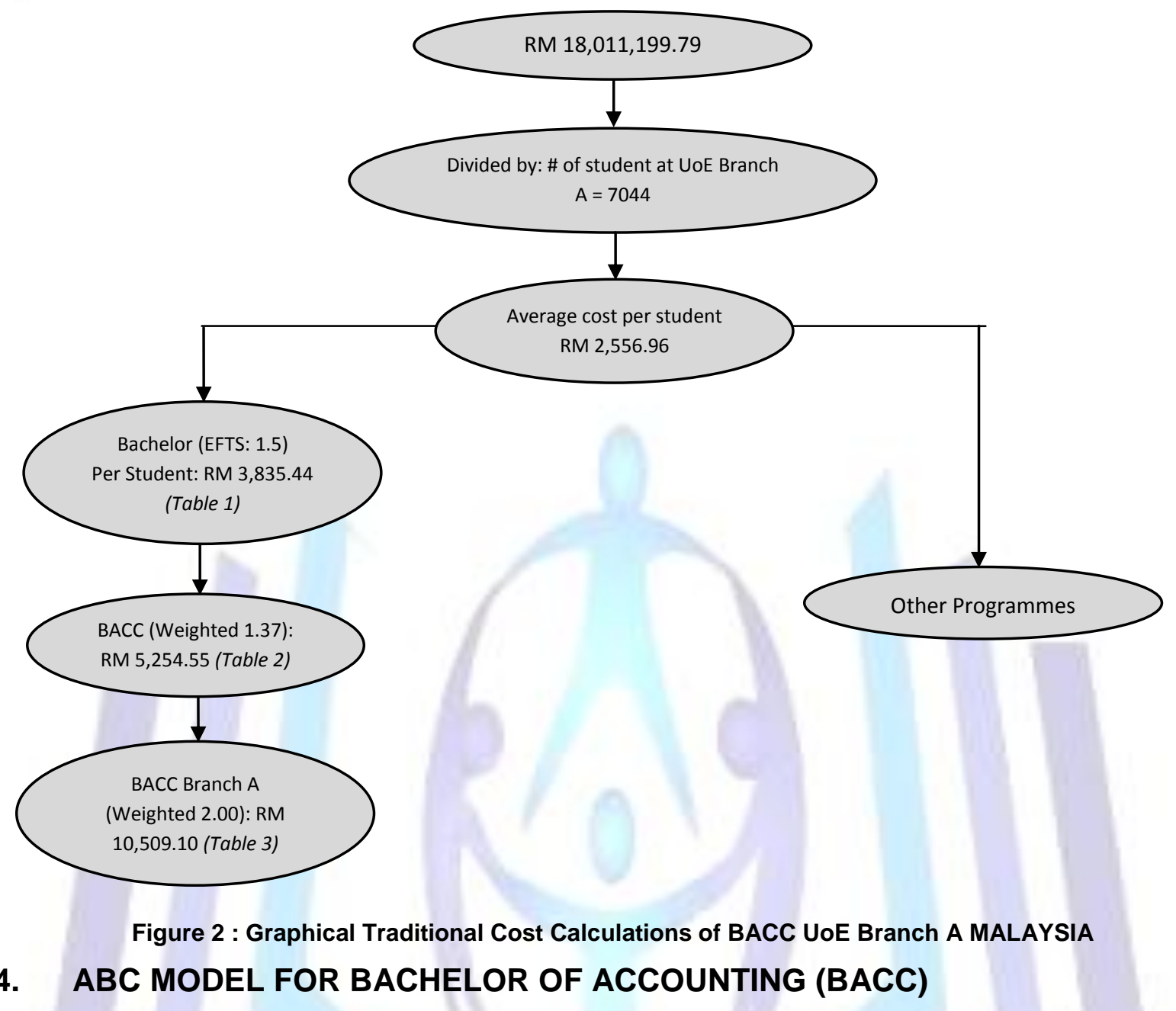

\subsection{General overview}

The model was developed in two phases. Phase I focused on, (1) identifying the resources consumed, (2) reclassifying the cost centres to the cost pools, (3) identifying cost object and. (4) identifying resources drivers. Phase II consists of three steps: (5) identifying activity drivers, (6) assigning cost from Resource Module to Activity Module, and (7) assigning cost from Activity Module to the Cost Object. These were summarised in Table 4.

\section{Table 4 : Steps in ABC Model development}

\begin{tabular}{||l|l|l||}
\hline Phases & Steps & \multicolumn{1}{|c|}{ Activities } \\
\hline Phase I & Step 1 & Identify the resources \\
\cline { 2 - 3 } & Step 2 & Reclassifying Cost Centres to Cost Pools \\
\cline { 2 - 3 } & Step 3 & Identify the Cost Object \\
\cline { 2 - 3 } & Step 4 & Identify Resources Drivers \\
\hline Phase II & Step 5 & Identify Activity Drivers \\
\cline { 2 - 3 } & Step 6 & $\begin{array}{l}\text { Assigning cost from Resource Module to the Activity } \\
\text { Module }\end{array}$ \\
\cline { 2 - 3 } & Step 7 & $\begin{array}{l}\text { Assigning cost from Activity Module to the Cost Object } \\
\text { Module }\end{array}$ \\
& & \\
\hline
\end{tabular}


Figure 3 shows the general overview of $A B C$ Model for UoE Branch A. As can be seen, its consist of three modules namely, i) Resource Module, ii) Activity Module, and iii) Cost Object Module. Resource Module and Activity Module consists of five sub-modules with only one sub-module for the Cost Object Module.

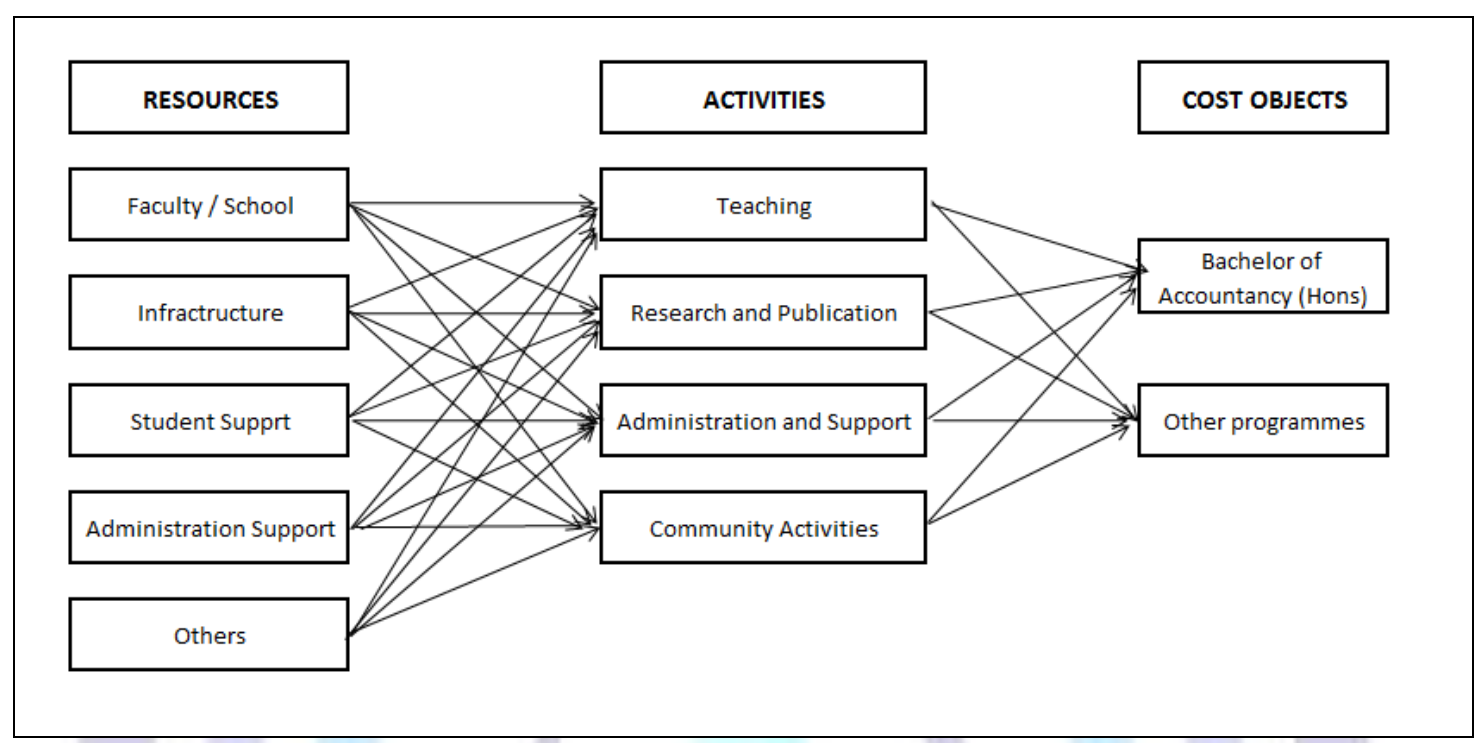

Figure 3 : The General Overview of ABC Model for UoE Branch A

\subsection{Resource Module}

Resources can be defined as the capacity to perform work, due to their "ability to represent all the available means that work activities can draw on." (Cokins, 2001: 48). With regards to the HEl environment, Granof et al., (2000) noted that resources are the annual expenditure incurred by academic and non-academic units for the specific fiscal year. Examples of resources are salaries, operating supplies and electricity bills.

On the practical number of cost pools, Goddard and Ooi (1998) and Xavier (2001) suggested between five to eight cost pools. Accordingly, the present study reclassified the cost centre form Chart of Account (COA) into five cost pools as can seen in Figure 4. This was subsequently finalised with the Bursar of UoE.

\begin{tabular}{|c|c|c|c|}
\hline \multicolumn{2}{|c|}{ COST CENTRES } & \multicolumn{2}{|c|}{ COST POOLS } \\
\hline Emoluments & $R M X X$ & Faculty/ School & $\mathrm{RM} X \mathrm{X}$ \\
\hline Claims and Milage & $\mathrm{RM} X \mathrm{X}$ & Infrastructure & $\mathrm{RM} X \mathrm{X}$ \\
\hline Asset & $R M X X$ & Student Support & $\mathrm{RM} X \mathrm{X}$ \\
\hline $\begin{array}{l}\text { Gifted and Fixed } \\
\text { Charges }\end{array}$ & $\mathrm{RM} X \mathrm{X}$ & Administration Support & $R M X X$ \\
\hline Other expenses & $R M X X$ & Others & $\mathrm{RM} X \mathrm{X}$ \\
\hline
\end{tabular}

Total Resources Costs: $\mathbf{R M} \mathbf{X X X . X X X . X X}$

Figure 4 : Comparison of Cost Centres and Cost Pools: UoE Branch A

There are two major components of resource module: (i) the salary received by staff, and (ii) the claims made by all academic staff either for their part time lectures (for lecturers) or their overtime (for other academic staff). The major cost components of Faculty / School consisted of both academic staff (lecturers and other academic staff), they may claim for mileage, accommodation, and other related claims. For Infrastructure, all expenses incurred by the Facility Department at the respective campus were directly charged to the campus account as well. For the purpose of simplicity, the present study only considers to include between three to five most frequent activities by lecturers in the module. For the Student Support sub-module, the list of staff at the Student Support Department (SSD) as provided by the Department of Student Affairs (DSA), consisted of 55 staffs. The cost for staff at DSA covered the Emoluments (including Wages and Salaries, Allowances, Contribution) to the Supplies and Charges, Claim and Mileage. Other 
costs, like Supplies and Charges; Claim and Mileage were also considered. The forth sub-module, Administration Support represent the biggest number of personnel which consisted of 131 personnel representing two major subdivisions, namely i) Administration and Security, and ii) Bursary Office. There are 118 personnel in the Administration and Security division and 13 staff under the Bursary office. With regard to the "Other / General Purposes" which consisted of the cost items which either are not frequently in use or that the cost items is widely serving across many areas in the administration. Examples of the cost items under this sub-module include road tax and insurance for motor vehicles.

\subsection{Activity Module}

An activity is work performed in transforming inputs into outputs (Brimson and Antos, 1999). It is a set of tasks that the organisation perform to account for cost, or analyse as a group while deriving both inputs and outputs (Keller, 1997). As such, activity is "a combination of people, technology, raw materials, methods and environment that produces a given product or service.

\subsubsection{Classification of activities}

As for $\mathrm{HEl}$, the activities can be classified into four major levels: unit, batch, product and facility (Drury and Tayles, 2005; Tatikonda and Tatikonda, 2001). Unit level activity is the activities that are performed each time a unit is produced, with inputs consumed are in direct proportion to the number of units produced. The batch-level activities are activities that are performed each time a batch of units is produced. Faculty compensation includes direct faculty costs; for example salary, benefits and support for teaching and staff at departments. On the other hand, related costs include salaries, benefits and support for the general administration and overheads. The facility-level activities are activities that are required to sustain the facility's overall functioning. These costs are either allocated on an arbitrary basis or not allocated at all. Examples of the activities classified under this category are corporate headquarters' costs and salaries of campus directors at the branch campuses.

The present study attempts to have five core headings for the activities module, namely (i) Teaching, (ii) Research and Consultancy, (iii) Professional Development, (iv) Administration and Support, and (v) Community Activities. The based model is then modified before the list of activities is finalised.

\subsubsection{Methods used to define activities}

Several researchers noted that various activities may be applicable based on different focus areas, which may lead to the different approaches of the data collection process. For example, several researchers (see Newman (2003), Heaney (2004) and Goddard and Ooi (1998)) used the interview method to define such activities. DETYA (2000) provided two additional methods, namely (i) surveys and ii) Workshops. As the first, surveys were run to gather opinions on what were the core activities that should be included in the activities module. Following to that, series of workshops were handled to refine the list.

\subsection{Cost Object module}

A cost object can be defined as "any activity for which a separate measurement of costs is desired" (Drury, 2001: 21). As such, cost objects represent the broad varieties of outputs and services where costs accumulate (Cokins, 1996). Brimson and Antos (1999) suggested that the cost objects are "..persons or things that benefit from incurring work activities" (Brimson and Antos, 1999 : 48). Some examples of cost objects include products, service lines, distribution channels, customers and outputs of internal process.

\subsubsection{Cost objects in HEI}

As revealed by previous studies, there is no specific rule on how to choose or classify cost objects. It depends on the objectives of a particular study (see Alejandro, 2000; Cook, 2003; Granof et al., 1998). With regard to the present study, one of its major objectives is to develop an $A B C$ model to determine the cost of a particular programme, i.e. BACC in UoE Branch A. As such, the cost object in this study is the Bachelor of Accountancy (BACC) programme.

\subsubsection{The BACC programme as a cost object}

The Accountancy faculty is an ideal programme because: i) Accountancy study is known to be one of the "core" faculties in UoE, ii) Accountancy programmes was the most established programme. this can be seen through strong collaborations that exist between the faculty and other renowned parties, such as the Malaysian Institute of Accountants (MIA), Association of Certified Chartered Accountants (ACCA) and The Chartered Institute of Management Accountants (CIMA).

\subsection{Cost drivers module}

A cost driver can be defined as a measurable factor that is used to assign costs to cost objects (Keller, 1997). Evans (2004) defined a cost driver as the mechanism that causes an activity to be performed or a resource to be used. The two types of cost drivers identified are: (i) resources driver, and (ii) activities driver. 


\subsubsection{Resource Drivers}

The resource driver is used to assign the resources to activities, while the activity driver is used to assign the costed activities to cost objects (Tatikonda and Tatikonda, 2001). It is worth to note that the amount of resource drivers needed to assign resources to the cost pools (in the Activity module) depends on how many resource groups are classified and the number of group activities listed in the Activity module. The present study will use the time allocated (percent) to assign cost from Faculty/School to the Activity Module.

\subsubsection{Activity Drivers}

Like resource cost drivers, activity cost drivers represent a logical and quantifiable relationship between the activities and cost objects (in this case, the BACC programme). Based on candidates suggested by the DETYA (2000), Table 5 lists the detailed candidates of drivers in the Activity module.

The confirmation of choosing them was based on the workshops conducted with selected personnel including Head Of Department (HOD) and coordinators of programmes, i.e. the faculty administration. The first source, i.e. HOD, provided the list of activity drivers followed by the faculty administration. As a summary, Table 6 presents the respective activity driver and its quantity, while Table 7 summarised the Resource Module, Resource Driver Quantity (RDQ) and resource drivers. Its followed by Figure 5 that shows the Graphical Illustration of ABC Model for BACC UoE Branch A Malaysia.

Table 5: $\quad$ Activity Module and Candidates of Activity Drivers

\begin{tabular}{|c|c|c|}
\hline Activity Module & $\begin{array}{c}\text { Assigned to (Cost } \\
\text { Object) }\end{array}$ & Candidates of Activity Drivers \\
\hline Teaching & BACC & $\begin{array}{l}\text { 1. No. of students } \\
\text { 2. No. of Assignment } \\
\text { 3. No. of examinations } \\
\text { 4. No. of Examination hours } \\
\text { 5. No. of student consultation hours } \\
\text { 6. No. of lecture hours } \\
\text { 7. No. of Tutorial hours } \\
\text { 8. No. of contact hours } \\
\text { 9. No. of teaching hours }\end{array}$ \\
\hline $\begin{array}{l}\text { Research and } \\
\text { Publication }\end{array}$ & BACC & $\begin{array}{l}\text { 1. No. of research project hours } \\
\text { 2. No. of innovation }\end{array}$ \\
\hline $\begin{array}{l}\text { Professional } \\
\text { Development }\end{array}$ & BACC & $\begin{array}{l}\text { 1. No. of conferences attended } \\
\text { 2. No. of training }\end{array}$ \\
\hline Administration Support & BACC & $\begin{array}{l}\text { 1. No. of hours (administration) } \\
\text { 2. No. of meeting attended } \\
\text { 3. No. of Committee involved } \\
\text { (Administration) } \\
\text { 4. No. of students }\end{array}$ \\
\hline Community Services & BACC & 1. No. of community project \\
\hline
\end{tabular}


Table 6 : Summary of Activity Drivers Quantity for Accounting Module

\begin{tabular}{|c|c|c|c|}
\hline \multirow[t]{2}{*}{ Activity Module } & \multicolumn{2}{|c|}{$\begin{array}{c}\text { Assigned to (Cost } \\
\text { Object) } \\
(\%)\end{array}$} & \multirow[t]{2}{*}{ Candidates of Resource Drivers } \\
\hline & BACC & Others & \\
\hline Teaching & 62.00 & 38.00 & - Number of Teaching Hours \\
\hline $\begin{array}{l}\text { Research and } \\
\text { Publications }\end{array}$ & 15.00 & 85.00 & $\begin{array}{l}\text { - Number of Researches Project } \\
\text { Hours }\end{array}$ \\
\hline $\begin{array}{l}\text { Professional } \\
\text { Development }\end{array}$ & 4.00 & 96.00 & - Number of Training \\
\hline Administration Support & 5.00 & 95.00 & - Number of Students \\
\hline Community Services & 8.75 & 91.25 & - Number of community projects \\
\hline
\end{tabular}

Table 7 : Summary of Resource Drivers and Quantity

\begin{tabular}{|c|c|c|c|}
\hline $\begin{array}{l}\text { Resource } \\
\text { Module }\end{array}$ & $\begin{array}{l}\text { Assigned to (Activity sub- } \\
\text { module) }\end{array}$ & $\begin{array}{l}\text { Resource Driver } \\
\text { Quantity (RDQ) }\end{array}$ & $\begin{array}{l}\text { Resource } \\
\text { Drivers }\end{array}$ \\
\hline Faculty / School & $\begin{array}{l}\text { Teaching } \\
\text { Research and Publication } \\
\text { Professional Development } \\
\text { Administration \& Support } \\
\text { Community Activities }\end{array}$ & $\begin{array}{r}60 \\
12 \\
10 \\
16 \\
2\end{array}$ & Time Allocated \\
\hline Infrastructure & $\begin{array}{l}\text { Teaching } \\
\text { Research and Publication } \\
\text { Professional Development } \\
\text { Administration \& Support } \\
\text { Community Activities }\end{array}$ & $\begin{array}{r}28,194.92 \\
20,309.34 \\
5,526.39 \\
101,546.35 \\
72,029.89\end{array}$ & Square Meter \\
\hline Student Support & $\begin{array}{l}\text { Teaching } \\
\text { Research and Publication } \\
\text { Professional Development } \\
\text { Administration \& Support } \\
\text { Community Activities }\end{array}$ & $\begin{array}{r}28,194.92 \\
20,309.34 \\
5,526.39 \\
101,546.35 \\
72,029.89 \\
\end{array}$ & Square Meter \\
\hline $\begin{array}{l}\text { Administration } \\
\text { Support }\end{array}$ & $\begin{array}{l}\text { Teaching } \\
\text { Research and Publication } \\
\text { Professional Development } \\
\text { Administration \& Support } \\
\text { Community Activities }\end{array}$ & $\begin{array}{r}0 \\
0 \\
0 \\
100 \\
0\end{array}$ & $\begin{array}{l}\text { Direct } \\
\text { allocation }\end{array}$ \\
\hline Others & $\begin{array}{l}\text { Teaching } \\
\text { Research and Publication } \\
\text { Professional Development } \\
\text { Administration \& Support } \\
\text { Community Activities }\end{array}$ & $\begin{array}{r}60 \\
12 \\
10 \\
16 \\
2\end{array}$ & Time Allocated \\
\hline
\end{tabular}




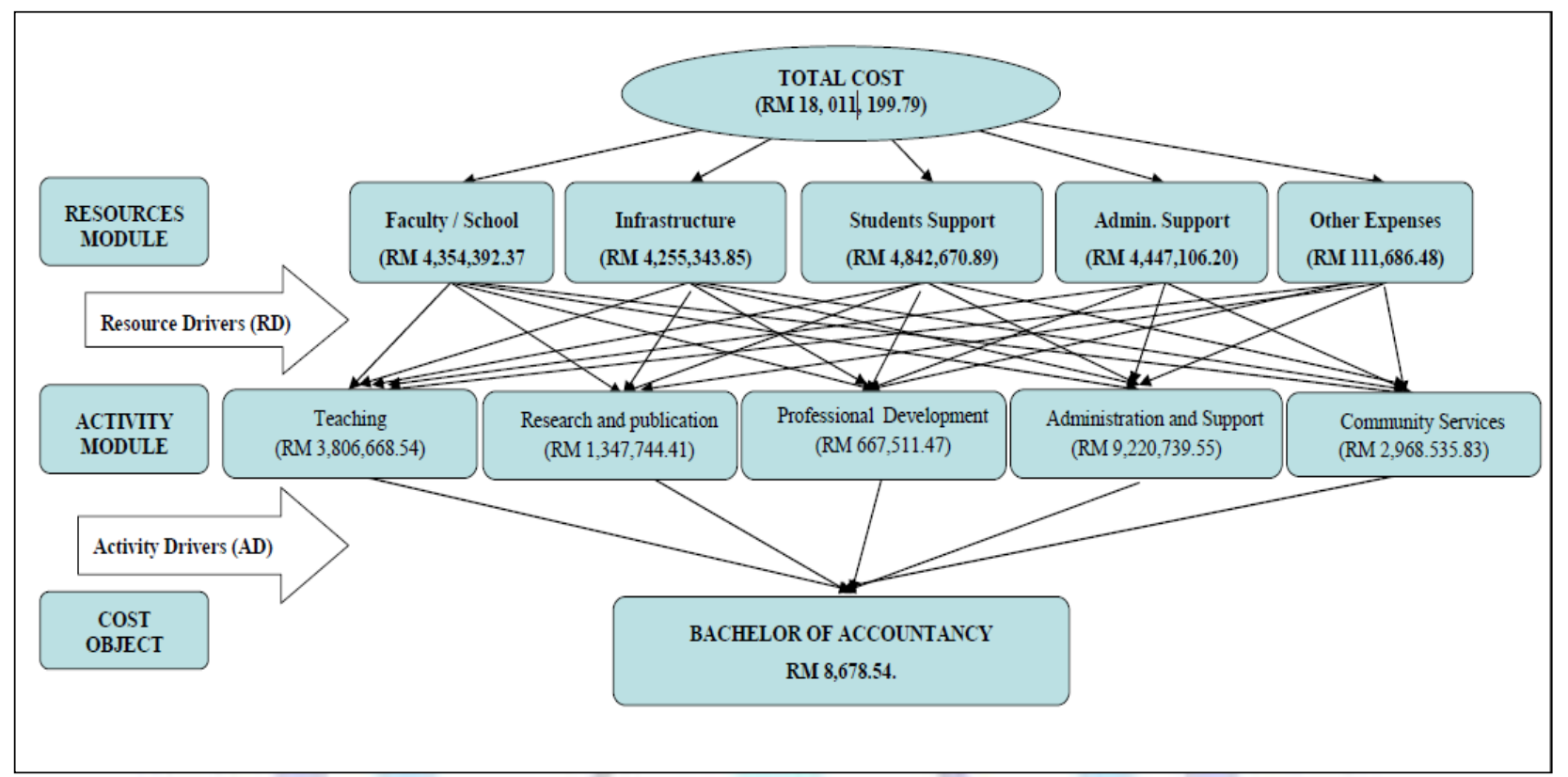

Figure 5: Graphical Illustration of ABC Model for UoE Branch A

\section{COST COMPARISONS BETWEEN ABC AND TCS}

Table 8 shows the cost comparison between TCS and the ABC system. As can be seen, the cost per programme using traditional costing revealed higher cost amounting RM 4,014,472.38 as compared to ABC system amounting RM 3,315,202.28. The difference of RM 1,830.55 (RM 10, 509.09 using TCS and RM 8,678.54 using ABC) per student was not surprising. It is expected as many other researchers have discovered the same pattern on the lower cost of ABC as compared to the traditional method (see Alejandro, 2000; Evans, 2004, Granof et al., 2000). Among a major reason of higher expenditure per student results from the inability of the organisation's costing system in spreading their costs over larger numbers of students, as can be seen by the usage of traditional costing system over ABC. Another reason noted by Granof et al., (2000), is that support services do not benefit the programmes uniformly and there were internal cross-subsidies among departments. Moreover they stated also that the programme costs would therefore be seriously distorted if support costs were allocated based on head counts.

Table 8 : Cost Comparison - Traditional and ABC

\begin{tabular}{||l|r|l|c||}
\hline \multicolumn{2}{|c|}{ Traditional Costing } & \multicolumn{2}{c|}{ Activity-based Costing (ABC) System } \\
\hline \multicolumn{1}{|c|}{ Cost Centres } & $\mathbf{R M}$ & \multicolumn{1}{c|}{ Cost Pools } & RM \\
\hline $\begin{array}{l}\text { Emoluments } \\
\text { (Salaries and Benefit) }\end{array}$ & $8,388,880.47$ & Faculty School & $4,354,392.37$ \\
\hline Claims and Mileage & $8,871,388.73$ & Infrastructure & $4,255,343.85$ \\
\hline Assets & $225,427.77$ & Student Support & $4,842,670.89$ \\
\hline $\begin{array}{l}\text { Gifted and Fixed } \\
\text { Charges }\end{array}$ & $413,816.31$ & Administration & $4,447,106.20$ \\
\hline $\begin{array}{l}\text { Other / General } \\
\text { Expenses }\end{array}$ & $111,686.51$ & Others & $111,686.48$ \\
\hline Total Cost & $18,011,199.79$ & Total Cost & $18,011,199.79$ \\
\hline Cost per student (BACC) & $\mathbf{1 0 , 5 0 9 . 0 9}$ & $\begin{array}{l}\text { Cost per student } \\
\text { (BACC) }\end{array}$ & $\mathbf{8 , 6 7 8 . 5 4}$ \\
\hline $\begin{array}{l}\text { Cost per programme } \\
\text { (382 students) }\end{array}$ & $4,014,472.38$ & $\begin{array}{l}\text { Cost per } \\
\text { programme } \\
\text { (382 students) }\end{array}$ & $3,315,202.28$ \\
\hline \hline
\end{tabular}




\section{ISSUES IN DEVELOPING ABC MODEL}

The present study roused several issues. First, the ABC model was developed based on the direct calculation of the actual cost allocated to the specific campus without using any "weights" to calculate the cost per student using traditional costing system. The purpose of this is to evaluate the actual potential of $A B C$ and should be free from any adjustments (including weights) and purely rely on the actual cost. Second, the ABC model was developed by using data for a single year in a single campus on a single programme (BACC). Thus this will limit its generalisability of the $A B C$ model. Third, the process of identifying the resource drivers. As for the present study, the percentage of effort used as resource drivers were obtained through surveys made on the HOS and the faculty management. However, this method can only provide accurate data when it is gathered on a regular basis from a wide range of participants. Obtaining information of past events by proxy however, has inherent limitations. For example, the trial study was constrained by the fact that the costs data collected were only for a period of one year. This was primarily due to the unavailability of data at the university or the faculty. As such, this might not be accurate because the cost incurred within a period of one year may not represent the cost incurred during the entire BACC programme. Similarly, the percentage of effort consumed by activities was also collected for the same period. The data collected may not be accurate because a better data should be collected using systematic and "ongoing" data collection process.

\section{SUGGESTIONS FOR FUTURE RESEARCH}

The future studies to develop ABC models in a similar setting needs to consider using the "weighted figures" to calculate the cost per unit (either per programme or per student) to fairly compare with the existing costing model. It should cover at least all three campus types (S\&T, SSH and BM) rather than focusing on a single campus type, as in the present study (i.e., Branch A campus represents the BM campus type). By doing this, the usefulness of ABC information can be generalised across various purposes of administrative aspect, such as academic and nonacademic affairs as well as public affairs (including relations with the media, the community, and local, state, and federal governments). As different campus types and stakeholders may perform different types of activities, the development of $A B C$ model across all types of campuses will increase the generalisability of the model.

Other than that, future research should collect all related data (including data on cost drivers, activities consumed and cost incurred) on an ongoing basis which should cover across several semesters or years. Without an enormous amount of detail and rich data collection, the model is limited in generalising its applications into another setting. As such, it will not be possible to undertake 'what if' analyses questions with respect to the existing courses, development of new courses, management of researches or consultancy projects, and permission of pricing for tendering and consultancy purposes.

\section{References}

[1] Alejandro, J. N. (2000). Utilizing an Activity-Based Approach for Estimating the Costs of College and University Academic Programs. Unpublished PhD Thesis, Baylor University, Waco, Texas.

[2] Amizawati Mohd Amir, Sofiah Md. Auzair, Ruhanita Maelah, and Azlina Ahmad. (2012). Determination of Educational Cost in Public University - A Modified Activity Based Approach. World Journal of Social Sciences, 2(2), 34 - 48.

[3] Brimson, J. A., and Antos, J. (1999). Driving Value Using Activity-Based Budgeting. New York: John Wiley \& Sons, Inc.

[4] Clarke, P. J., and Mullin, T. (2001). Activity Based Costing in the non-manufacturing sector in Ireland : A preliminary Investigation. The Irish Journal of Management, 1 - 18.

[5] Cohen, S., Venieris, G., and Kaimenaki, E. (2005). ABC: adopters, supporters, deniers and unawares. Managerial Auditing Journal, 20(9), 981 - 1000.

[6] Cokins, G. (1996). Activity-Based Cost Management: Making it Work. New York McGraw Hill.

[7] Cox, K. S., Downey, R. G., and Smith, L. G. (2007). Activity Based Costing and Higher Education - Can it Work.

[8] Drury, C., and Tayles, M. (2005). Explicating the design of overhead absorption procedures in UK organizations. The British Accounting Review, 37, 47 - 84.

[9] Evans, T. M. (2004). Activity-Based Costing at Colleges and Universities: Understanding, Communicating and Controlling Costs Associated with Educating Different Student Groups. Unpublished PhD Thesis, The University of Texas at Austin, Texas.

[10] Goddard, A., and Ooi, K. (1998). Activity-Based Costing and Central Overhead Cost Allocation in Unversities: A Case Study. Public Money \& Management, 18(3), 31 - 38. 
[11] Granof, M. H., Platt, D. E., and Vaysman, I. (2000). Using Activity-Based Costing to Manage More Effectively: Department of Accounting, College of Business Administration, University of Texas at Austin.

[12] Heaney, M. (2004). Easy as ABC? Activity-based costing in Oxford University Library Services. The Bottom Line - Managing Library Finances, 17(3), 93 - 97.

[13] Hilton, R. W. (2001). Managerial Accounting : Creating Value in a Dynamic Business Environment (5th ed.). New York: McGraw Hill, Irwin.

[14] Holst, R., and Savage, R. J. (1999). Tools and Implementing Activity-Based Management. In S. Player \& R. Lacerda (Eds.), Arthur Andersen's Global Lessons in Activity-Based Management (pp. 268). New York: John Wiley \& Sons, Inc.

[15] Jamaliah Abdul Majid, and Maliah Sulaiman. (2008). Implementation of activity based costing in Malaysia: A case study of two companies. Asian Review of Accounting, 16(1), 39 - 55.

[16] Keller, J. (1997). Activity-Based Costing and Management Tools in Government and the Private Sector. Altamonte Springs: The Institute of Internal Auditors

[17] Khrisnan, A. (2006). An application of Activity Based Costing in higher learning institution : A local case study. Comtemporary Management Research, 2(2), 75 - 90.

[18] Newman, J. E. (2003). Activity-Based Costing in User Services of an Academic Library. Library Trends, 51(3), 333 - 348.

[19] Noor Azizi Ismail. (2006). Activity-Based Management For Higher Education Institutions. Accountants Today.

[20] Tatikonda, L. U., and Tatikonda, R. J. (2001). Activity-Based Costing for Higher Education Institutions. Journal of Higher Education Policy and Management, 33(4), 70 -78.

[21] Xavier, J. A. (2001). Budgeting for Performance - Principles and Practice (1st ed. Vol. 1). Kuala Lumpur: National Institute of Public Administration (INTAN). 